\title{
LEARNING FROM BELOW: THEORISING GLOBAL GOVERNANCE THROUGH ETHNOGRAPHIES AND CRITICAL REFLECTIONS FROM THE GLOBAL SOUTH
}

\section{Sujith Xavier*}

This paper explores the various means by which we can overcome the universalism imbedded in international law and international institutions. It asks: How can international lawyers and international law scholars learn from the Global South? This 'how' question prompts another, but related question: should we learn from the Global South?

There is a rich interdisciplinary body of literature that signals to the Global South, or Europe's other, as a site of knowledge production. The eurocentrism of the social sciences can be identified by examining the various founding fathers of their respective theories (especially sociology). This paper builds on southern theory in order to learn from these diverse perspectives in theorising global governance.

This paper is organised in three sections. First, it sets out the rationale for a reorientation towards the Global South by examining the current state of global governance theory. In the second section, this paper focus on the broad theoretical foundations of the Third World Approaches to International Law [TWAIL] movement. TWAIL scholarship is a reaction against the colonial and imperial projects of international law. Its main claims are set out and then there is an examination of its proposals as a means to arrive at an answer to the second question: should we learn from the Global South?

In the final section, this paper explores the question of how we can learn from the Global South. In answering this question, the author offers two insights. The first is based on the premise of international law as a field of practice. The second attempts to problematise the ethics of international legal scholarship.

Dans cet article, l'auteur examine les divers moyens par lesquels on peut surmonter l'universalisme dont le droit international et les institutions internationales sont pétris. Il pose la question de savoir comment les avocats en droit international et les universitaires faisant des travaux en droit international peuvent apprendre quelque chose du Sud. Cette question en soulève une autre, qui est liée : celle de savoir si nous devrions apprendre quelque chose du Sud.

* $\quad$ Dr. Sujith Xavier, LL.B., LL.M., is an Assistant Professor at the Faculty of Law, University of Windsor. I like to extend my sincerest appreciation to my doctoral committee (Peer Zumbansen, Ruth Buchanan and Bruce Broomhall) for their advice and generosity. I owe a debt of gratitude to Antony Anghie, Nergis Canefe and Obiora Okafor for their invaluable comments and suggestions in course of my doctoral exam. I am grateful to my "co-conspirators" on this journey, Amar Bhatia, Usha Natarajan and John Reynolds for creating an inclusive space to organise an amazing conference. Finally, I am thankful to Sam Hale for the research assistance. All errors are mine. 
Il existe un riche corpus interdisciplinaire d'écrits qui indiquent que le Sud ou l'autre périphérie de l'Europe sont des lieux de production de connaissances. On peut déceler l'eurocentrisme des sciences sociales en étudiant les différents pères fondateurs de leurs théories respectives (surtout en sociologie). Dans cet article, l'auteur fait fond sur la théorie du Sud pour tirer des enseignements de ces diverses perspectives en formulant une théorie sur la gouvernance mondiale.

Cet article est divisé en trois parties. Dans la première, l'auteur expose la justification d'une réorientation vers le Sud en étudiant l'état de la théorie de la gouvernance mondiale. La deuxième partie porte sur les fondements théoriques généraux du mouvement Third World Approaches to International Law (TWAIL). La mission universitaire de TWAIL est une réaction contre les projets de droit international coloniaux et impérialistes. L'auteur expose les principales assertions de ce mouvement, puis il examine ses propositions comme moyen d'arriver à une réponse à la seconde question, qui est de savoir si nous devrions apprendre quelque chose du Sud.

Dans la troisième et dernière partie, l'auteur analyse la question de savoir comment nous pouvons apprendre quelque chose du Sud. En y répondant, il présente deux théories. La première est fondée sur la prémisse posant le droit international comme champ d'exercice. La deuxième tente de poser le problème de l'éthique de la recherche universitaire en droit international.

\section{INTRODUCTION}

There is a democracy deficit in contemporary global governance. The deficit stems from a lack of participation and accountability within international institutions. The democracy deficit is often credited to the various modes of globalisation $(s)^{1}$, fragmentation of international law and its institutions ${ }^{2}$. International legal scholars and international lawyers theorise global governance using multiple theoretical perspectives. ${ }^{3}$ Scholars and practitioners working in this type of theory production suggest that it is possible to usher in accountability and legitimacy through global constitutionalism and global administrative law. ${ }^{4}$ There are a number of limitations to this type of theory. ${ }^{5}$

1 Boaventura de Sousa Santos, Toward a New Legal Common Sense: Law, Globalization, and Emancipation (London: Butterworths LexisNexis, 2002) at 179 [Santos, New Legal Common Sense]; Boaventura de Sousa Santos, "Globalizations" (2006) 23 Theory Culture Society 292 at 296 [Santos, "Globalizations"].

2 Bruno Simma \& Dirk Pulkowski, "Of Planets and the Universe: Self-Contained Regimes in International Law" (2006) 17:3 Eur J Intl L 483 at 484.

3 Kevin Davis, Benedict Kingsbury \& Sally Engle Merry, "Introduction: Global Governance by Indicators" in Kevin Davis et al, eds, Governance by Indicators: Global Power through Quantification and Rankings (Oxford: Oxford University Press, 2015) at 10-21.

4 Jeffrey L Dunoff \& Joel P Trachtman, “A Functional Approach to International Constitutionalization” in Jeffrey L Dunoff \& Joel P Trachtman, eds, Ruling the World; Constitutionalism, International Law, and Global Governance (Cambridge: Cambridge University Press, 2009) at 5-9; Peters \& Armingeon regard it as "constitutionalist spectacles", Anne Peters \& Klaus Armingeon, "Introduction-Global Constitutionalism from an Interdisciplinary Perspective" (2009) 16:2 Ind J Global Leg Stud 385 at 385; Nico Krisch \& Benedict Kingsbury, "Introduction: Global Governance 
A handful of scholars have already sought to provide incisive critiques of these moves to transfer domestic conceptions of law to the global sphere. ${ }^{6}$ In this paper, my central aim is to ask: how can we ${ }^{7}$ learn from the Global South in theorising global governance? Ultimately, this paper proposes a deep engagement with scholarly interventions that explore the lived realities of the people of the Global South.

There are various forms of global governance theories. Global legal pluralism ${ }^{8}$ and transnational legal pluralism ${ }^{9}$, for example, attempt to move beyond domestic analogies. However, in this paper, I focus on two theories that borrow from domestic conceptions of law: global constitutionalism and global administrative law.

Global constitutionalism identifies existing legitimacy-producing mechanisms in international law and its institutions. Scholars suggest that international law and its institutions exhibit characteristics akin to constitutionalism and constitutionalisation. ${ }^{10}$ They further argue that international law should be used to create a better world by imagining a constitutional future. ${ }^{11}$ The United Nations Charter, for example, is imagined as a world constitution. ${ }^{12}$

Global administrative law focuses on global governance as administration. ${ }^{13}$ Contemporary international institutions are making use of administrative law principles. ${ }^{14}$ Some scholars that work on global administrative law are from Anglo-Saxon jurisdictions. They identify administrative law norms

and Global Administrative Law in the International Legal Order" (2006) 17 Eur J Intl L 1; Benedict Kingsbury, "The Administrative Law Frontier in Global Governance" (2005) American Society of International Proceedings 143.

5 Martin Loughlin, "Constitutional Pluralism: An Oxymoron?" (2014) 3:1 Global Constitutionalism 9 at 14; Carol Harlow, "Global Administrative Law: The Quest for Principles and Values" (2006) 17:1 Eur J Intl L 187 at 190; BS Chimni, "International Institutions Today: An Imperial Global State in the Making" 15:1 Eur J Intl L; Susan Marks, "Naming Global Administrative Law" (2005) 37 NYUJ Intl L \& Pol 995 at 995.

6 BS Chimni, "Co-option and Resistance: Two Faces of Global Administrative Law" (2006) 37 NYUJ Intl L \& Pol 799 [Chimni, "Co-option"]; Zoran Oklopcic, "Provincializing Constitutional Pluralism" (2014) 5:3 Transnational Legal Theory 331.

7 The "we" that this paper is concerned with includes scholars from the Global North and Global South, and legal practitioners from the Global North and Global South. For a greater examination of my own subject position as it relates to the Global South, see Sujith Xavier, Global Governance, Global Constitutionalism \& Global Administrative Law: False Universalisms? (PhD Thesis, Osgoode Hall Law School, 2015) [unpublished] [Xavier, False Universalisms].

8 Peer Zumbansen, “Transnational Legal Pluralism" (2010) 1:2 Transnational Leg Theory 141.

9 David Held, Global Covenant: The Social Democratic Alternative to the Washington Consensus (London: Polity Press, 2004); Jürgen Habermas, Divided West (Cambridge: Polity Press, 2006).

10 Ibid.

11 Neil Walker, "Constitutionalism and Pluralism in Global Context" in Matej Avbelj \& Jan Komarek, eds, Constitutional Pluralism in the European Union and Beyond (Oxford: Hart Publishing, 2012) at 17; A similar argument was recently made by global administrative law scholars, see Richard B Stewart, "The Normative Dimensions and Performance of Global Administrative Law" (2015) 13 (2) Intl J Constitutional L 499 at 500 [Stewart, "Normative Dimensions"].

12 Bardo Fassbender, UN Security Council Reform and the Right of Veto: A Constitutional Perspective (The Hague: Kluwer Law International, 1998).

13 Benedict Kingsbury, Nico Krisch \& Richard B Stewart, "The Emergence of Global Administrative Law" (2005) 68 Law and Contemporary Problems 15.

14 Ibid; Karl-Heinz Ladeur, "The Emergence of Global Administrative Law and Transnational Regulation” (2013) 3:3 Transnational Leg Theory 243. 
within international regimes by analogising from their national administrative framework. ${ }^{15}$ This type of analogising contributes to the universalising nature of international law.

Global administrative lawyers argue that the entire collection of norms, principles and doctrines that weave together domestic administrative law can be found within the regulatory structure of global governance institutions. ${ }^{16}$ By demonstrating the presence, or possibilities, of these norms, they suggest that the current international regulatory framework explicitly embodies or has the potential to produce accountability. ${ }^{17}$ Richard Stewart, one of the founders of global administrative law has suggested that: "Despite vast differences in institutional and political circumstances, experience confirms that use of administrative law mechanisms in global administration can help protect the rights of individuals threatened with sanctions and [...] secure greater regard for the politically weak and vulnerable". ${ }^{18}$

There are a number of problems with these attempts to usher in legitimacy and accountability within international law and its institutions. The central shortcoming of these two theories described above is that they ignore and obscure the true nature of international law and its institutions. This is nonetheless part of a larger trend in international law. This trend can be characterised as an attempt to deploy the western particular (i.e. notions of Canadian ${ }^{19}$ or European $^{20}$ constitutional law or notions of American ${ }^{21}$ or German ${ }^{22}$ administrative law) as a universal norm, applicable worldwide.

This endemic aspect of international law can be rooted in its history and the manner in which it was forged. The beginnings of international law are imbricated in a narrative of western universalism, starting with the manner in which the sovereignty doctrine was created. ${ }^{23}$ Irene Watson chronicles this process and suggests that "an evolving international law constituted by colonialism padded the relations between the rival colonial powers. To conceal its evil intent, colonialism was badged as a civilising mission, a mission to convert savagery into the universal civilisation of Europe". "24 This facet of international law has enduring legacies that have affected its development and continues to affect its institutions and doctrines. Much more importantly, these relics of colonialism and imperialism affect and influence the manner in which we theorise international law and its institutions now. ${ }^{25}$

15 Sabino Cassese et al, "Foreword" in Sabino Cassese et al, eds, Global Administrative Law: The Casebook (Rome Edinburgh New York: ILRP, 2012) at xxiii.

16 Ibid at xxiv.

17 Sujith Xavier, "Theorising Global Governance Inside Out: A Response to Professor Ladeur" (2013) 3 Transnational Leg Theory 268 [Xavier, "Response to Ladeur"].

18 Stewart, "Normative Dimensions", supra note 11 at 500.

19 Ronald St John Macdonald \& DM Johnston, eds, Towards World Constitutionalism: Issues on the Legal Ordering of the World Community (Leiden: Martinus Nihjoff, 2005).

20 Peters \& Armingeon, supra note 4.

21 Kingsbury, supra note 4.

22 Ladeur, supra note 14.

23 Antony Anghie, Imperialism, Sovereignty and the Making of International Law (Cambridge: Cambridge University Press, 2004) [Anghie, Imperialism].

24 Irene Watson, Aboriginal Peoples, Colonialism and International Law: Raw Law (New York: Routledge, 2015 ) at 6.

25 For a recent attempt to demonstrate the universalism of international law and international institutions, see Sundhya Pahuja, Decolonising International Law: Development, Economic Growth and the Politics of Universality (Cambridge: Cambridge University Press, 2011). 
This paper explores the various means by which we can overcome the universalism imbedded in international law and international institutions by asking: How can international lawyers and international law scholars learn ${ }^{26}$ from the Global South? The 'how' question prompts another, but related question: should we learn from the Global South? ${ }^{27}$

This paper builds on current literature on the Global South or what Raewyn Connell has coined "southern theory" in order to learn from diverse perspectives in theorising global governance. ${ }^{28}$ There is a rich interdisciplinary body of literature that signals to the Global South, or Europe's other, as a site of knowledge production. This particular body of work, at times cited to as alternative discourses, focuses on the "eurocentrism and often irrelevancy of mainstream discourses". ${ }^{29}$ The eurocentrism of social sciences can be identified by examining the various founding fathers of their respective theories (especially sociology). ${ }^{30}$

Sociologists have sought to open up space to think about the contribution of the Global South to our understanding of modernity. They then hope to reconstruct their field through the lens of connected sociologies. ${ }^{31}$ In the socio-legal context, a similar move is apparent in Boaventura De Sousa Santos' scholarship. He expressly calls for such a reorientation to the Global South. ${ }^{32}$ Santos argues that in the current socio-economic-political climate, we need theories that are not "vanguard"; rather, we need "rearguard" theories. He suggests that contemporary theoretical analysis should focus on social movements by asking questions, creating linkage with other social movements, overcoming difference and building bridges. He argues that we must "facilitate interactions with those that walk more slowly [...]" in places that were ignored or made invisible by "the Eurocentric critical tradition" ${ }^{33}$

Within legal spaces, other scholars have posited examples from the Global South as an interruption to the Eurocentric focus on constitutional theory. ${ }^{34}$ They challenge the manner in which we imagine the Global South. They argue that the Global South is not a carbon copy of the North; rather, it is unique in

26 For another account of a similar project in the context of international environmental law, see Kishan Khoday \& Usha Natarajan, "Fairness and International Environmental Law from Below: Social Movements and Legal Transformation in India" (2012) 25 Leiden J Intl L 415.

27 This second question is prompted by Sundhya Pahuja's astute reflection during an informal conversation during the TWAIL 2015 Cairo conference: should we theorise global governance from the perspectives of the Global South?

28 Raewyn Connell, Southern Theory (Cambridge: Polity, 2007).

29 Syed Farid Alatas, "An Introduction to the Idea of Alternative Discourses" (2000) 28:1 Southeast Asian J of Social Science 1.

30 Raewyn Connell, Southern Theory (Cambridge: Polity, 2007) at 4-18.

31 Gurminder K Bhambra, Connected Sociologies (London: Bloomsbury, 2014) at 3.

32 Jean Comaroff \& John Comaroff, Theory from the South: Or, How Euro-America is Evolving Toward Africa (The Radical Imagination) (London: Paradigm, 2012) [Comaroff and Comaroff]; Daniel Bonilla Maldonado, "Introduction" in Daniel Bonilla Maldonado, ed, Constitutionalism of the Global South (Cambridge: Cambridge University Press, 2013) 1 [Bonilla, "Introduction"].

33 Boaventura de Sousa Santos, Epistemologies of the South: Justice Against Epistemicide (London: Paradigm Publisher, 2014) at 44 [Santos, Epistemologies].

34 Bonilla, "Introduction", supra note 32; Jackie Dugard, "Courts and Structural Poverty in South Africa: To what extent has the Constitutional Court expanded access and remedies to the poor?" in Bonilla, supra note 32, 293; Manuel Iturralde, "Access to Constitutional Justice in Colombia: Opportunities and Challenges for Social and Political Change" in ibid, 361; Menaka Guruswamy \& Bipin Aspatwar, "Access to Justice in India: The Jurisprudence (and SelfPerception) of the Supreme Court" in ibid, 329. 
its development. This development therefore should be celebrated. From this vantage point, turning to the Global South provides an opportunity to glean new insights about international law and its institutions.

But what exactly do I mean by the Global South? My understanding of the Global South is built on interdisciplinary scholarship that shifts beyond the category of the Third World while retaining its salient features. ${ }^{35}$ The Global South is constructed through connected histories ${ }^{36}$ and connected sociologies. ${ }^{37}$ The connected histories call for an understanding of world history as world histories, structured by connected processes rather than fixed events. ${ }^{38}$ Bhambra's connected sociologies suggests a broader understanding of events that transcend our normal ordering of the world based on Eurocentric modernity to one that reconstructs the possibilities of our world.

My understanding of the Global South is one that aligns with Jean and John Comaroff's suggestion that it is a polythetic category where it has multiple features. ${ }^{39}$ They thus argue that the Global South "assumes meaning by virtue not of its content, but of its context, [...] to its antinomy to "the Global North', an opposition that carries a great deal of imaginative baggage congealed around the contrast between centrality and marginality, free-market modernity and its absence". ${ }^{40}$ It is thus something that cannot be defined and its material contents are determined by "everyday material and political processes". ${ }^{41}$ The everyday material reality is one that can be located in Attawapiskat First Nation in Northern Ontario, Canada or in the rural war ravaged villages of Vanni, Northern Province of Sri Lanka.

Vijay Prashad suggests that the Global South signifies a form of resistance to the transformations described above as the coming together of various forces. This is another layer that can be added to our existing understating of the Global South. Prashad argues that given the manner in which world politics operates, especially as a result of neoliberalism, the Global South has come to be identified with protests "against the theft of the commons, against the theft of human dignity and rights, against the undermining of democratic institutions [...]". 42

The Global South is a condition brought about by various forces of history including colonialism, imperialism, capitalism and resistance. It describes a relationship between the colonised and coloniser, as shaped by the forces of globalisation. Ultimately, it captures power relations at all levels between communities inside and outside established borders. The Global South does not encompass and fixate on one historical moment of first contact between Europeans and the "savages". Rather the Global South, in

35 See Xavier et al, "Placing TWAIL Scholarship and Praxis (Introduction to the Special issue of the Windsor Yearbook of Access to Justice)" (2016) 33:3 Windsor YB Access Just v; Balakrishnan Rajagopal, "Locating the Third World in Cultural Geography" (2000) 15:2 Third World Legal Stud 1; Karin Mickelson, "Rhetoric and Rage: Third World Voices in International Legal Discourse" (1998) 16:2 Wis Intl LJ 35; BS Chimni, "Third World Approaches to International Law: A Manifesto" (2006) 8 Intl Community L Rev 3.

36 Sanjay Subrahmanyam, "Connected Histories: Notes towards a Reconfiguration of Early Modern Eurasia" (1997) 31:3 Mod Asian Stud 735 at 745.

37 Bhambra, supra note 31.

38 Subrahmanyam, supra note 36 at 759-62.

39 Comaroff \& Comaroff, supra note 32 at 45.

40 Ibid.

41 Ibid.

42 Vijay Prashad, Poorer Nations (London: Verso, 2014) at 9. This point was made earlier by Boaventura de Sousa Santos as insurgent cosmopolitanism; Santos, New Legal Common Sense, supra note 1. 
my reading, is a space in which colonialism and imperialism, along with fast-paced growth through modern technologies, facilitate connections and dependencies. One crucial aspect of the term Global South is recognition that there are multitudes of claims in various spaces that are both emancipatory and oppressive. In particular, the possibility of a south in the North and a north in the South is key. This speaks to the recognition of Indigenous groups in the Global North as engendering a Fourth World. ${ }^{43}$

That said, we should be careful not to conflate Indigenous struggles for sovereignty with Global South struggles for equity, access and redistribution. The very logics of settler colonialism ${ }^{44}$ and external colonialism ${ }^{45}$ have bifurcated these two axes of resistance. ${ }^{46}$ While similarities do exist between these two types of resistance, the bifurcation has resulted in Indigenous peoples' claims being rooted to their indigenous lands and their own legal culture while the Global South claims are based on the search for further equality and equity. While noting the difference in these types of movements, my understanding of the Global South encapsulates a number of various claims predicated on historical progress, which includes Indigenous peoples, migrants, enslaved peoples and their descendants of the Global North.

These various complex but nuanced descriptions of the Global South are important and shape the direction of this paper. Ultimately, by adopting this broad and all-encompassing definition of the Global South, I hope to create new avenues to transcend the limitation of western universalism rooted within the global governance theories.

This paper is organised in three sections. In what follows, I will set out the rationale for a reorientation towards the Global South by examining the current state of global governance theory. In the second section, I will focus on the broad theoretical foundations of the Third World Approaches to International Law [TWAIL] movement. TWAIL scholarship is a reaction against the colonial and imperial projects of international law. I set out its main claims and then examine its proposals as a means to arrive at an answer to the question: should we learn from the Global South?

Then, I explore the question of how we can learn from the Global South. In answering this question, I offer two insights. The first is based on the premise of international law as a field of practice. Often, international lawyers and international law scholars tend to examine the legal mechanisms and the ensuing doctrines of international law without reference to geo-political, economic, social, and cultural contexts. Thinking about international law as a field of practice rather than solely focusing on issues of legality, can illuminate international law's unlit corners that are constituted by diverse sets of forces at play in today's society. In order to focus on international law as a field of practice, we must gather more insights about international law and its institutions through ethnographies. The second insight that I offer attempts to problematise the ethics of international legal scholarship. In this regard, I focus on the role of international lawyers and international law scholars and their ethical obligations in light of the material reality of the Global South.

43 Amar Bhatia, "The South of the North: Building on Critical Approaches to International Law with Lessons from the Fourth World" (2012) 14:1 Or Rev Intl L 131.

44 Patrick Wolfe, "Settler colonialism and the elimination of the native" (2006) 8:4 J Genocide Research 387.

45 Eve Tuck \& Wayne Yang, "Decolonization is not a metaphor" (2012) 1:2 Decolonization: Indigeneity, Education \& Society 1.

46 Maile Arvin, Eve Tuck, \& Angie Morrill, "Decolonizing Feminism: Challenging Connections between Settler Colonialism and Heteropatriarchy" (2013) 25:1 Feminist Formations 8 at 11-12. 
Importantly, this contribution to the Windsor Yearbook of Access to Justice TWAIL special issue is framed as an ambitious project. Some of the pieces included in this issue seek to transcend the limitations of global governance theories. The theories that are central to my analysis are global constitutionalism and global administrative law. These two theories attempt to usher in accountability to global governance institutions as means to overcome various limitations brought about by the democracy deficit alluded to earlier. There are a number of broad claims that are advanced in this paper. I frame them in this fashion as means to build bridges between different disciplinary silos of global governance, mainstream international law, Third World Approaches to International Law and other disciplines that have gestured towards the Global South as a site of knowledge production.

\section{STATE OF GLOBAL GOVERNANCE THEORY}

In his 2013 collection of essays titled, Constitutionalism of the Global South, Daniel Bonilla examines the state of contemporary constitutional theory. His scholarly contribution is to ask how the Colombian Constitutional Court, the Constitutional Court of South Africa, and the Indian Supreme Court can contribute to modern understandings of constitutionalism. ${ }^{47}$ His starting point is to recognise the Eurocentricism in constitutional theory. Constitutionalism is usually reliant upon western legal thinkers, which results in the exclusion of knowledge production from the Global South. Bonilla characterises this as the relegation of legal thinkers from the Global South to "particularly low level" priority and importance. ${ }^{48}$ This premise is a good starting point when thinking about contemporary global governance theory.

Bonilla makes five specific arguments in support of his thesis that constitutionalism is reliant upon western legal thinkers. First, the legal systems in the Global South are thought to reproduce the legal systems of the Global North. Second, western contributions to legal theory and the adoption of the western legal systems by countries in the Global South have reified the claim that the legal systems of the Global South are similar to the legal systems of the Global North. This reification has led to the notion that there is little value in understanding the Global South as a site of unique legal knowledge with rich legal traditions. ${ }^{49}$ Third, the indifference demonstrated by scholars of the Global North is based on an alleged formalism of the laws in the Global South, which ostensibly demonstrates the Global South's backwardness and underdevelopment. The fourth argument that Bonilla presents is that the academic knowledge production of the Global North is deemed to be much more robust than the academic knowledge production in the Global South. Finally, Bonilla stipulates that the "closed and parochial character of U.S. legal academy, along with the selective openness of most of Western Europe's legal academy, discourages any dialogue with the legal institutions of the Global South". 50

\footnotetext{
47 Bonilla, "Introduction", supra note 32 at 29.

48 Ibid at 4.

49 Ibid at 6.

50 Ibid at 11.
} 
Building on these five general claims, Bonilla generates three rules that "govern the production, circulation, and use of legal knowledge". ${ }^{51}$ These three rules are: the Well of Production rule ${ }^{52}$; the Protected Designation of Origin rule ${ }^{53}$; and the Effective Operator rule. ${ }^{54}$

According to the Well of Production rule, the Global North is the only place that is able to produce legal knowledge. This implies that the Global South is incapable of producing original knowledge and that the Global South simply replicates knowledge from other sources. Bonilla is accurate in his description of this normative tendency, which is prevalent in how scholars theorise global governance today. When discussing the descriptive accounts of global constitutionalism for example, there is a propensity to rely on European models, European authors and the European experience. ${ }^{55}$ This is similar for the global administrative law scholars who are from Anglo-Saxon jurisdictions. In the discussions about the descriptive accounts of global constitutionalism, Klabbers, Peters, and Ulfstein rely on principles from the European Union and its adjudicatory frameworks as an illustration of global constitutionalism. ${ }^{56}$ Klabbers, Peters, and Ulfstein's global constitutionalism is then meant to be applicable worldwide, in particular as it relates to global governance institutions that operate in the Global South.

The second rule - the Protected Designation of Origin rule- suggests that all knowledge produced in the North should be respected and recognised. This insight is extremely valuable to my analysis. Even though scholars from the Global South (and their allies) are active in international law and its institutions, their critical perspectives and interventions are not adopted into the literature of global administrative law ${ }^{57}$ and global constitutionalism. ${ }^{58}$

This critique is similar to the reflections of Richard Delgado in 1992 about civil rights scholarship. Delgado noted that an: "inner circle of twenty-six scholars, all male and white, occupied the central arenas of civil rights scholarship to the exclusion of contributions of minority scholars. When a member of this inner circle wrote about civil rights issues he cited almost exclusively to other members of the circle for support". ${ }^{59}$ Similarly, in the discussions about global administrative law and global

$51 \quad$ Ibid at 9.

52 "This states that the only context for the production of knowledge is the legal academia in the North"; Ibid.

53 "This indicates that all knowledge produced in the North is worthy of respect and recognition per se, given the context from which it emerges"; Ibid at 10.

54 "This rule indicates that academics and legal institutions from the North are much better trained to make effective and legitimate use of legal knowledge than academics and legal institutions from the South"; Ibid at 11.

55 Peters \& Armingeon, supra note 4.

56 Jan Klabbers, "Setting the Scene" in Jan Klabbers, Anne Peters \& Geir Ulfstein, eds, The Constitutionalization of International Law (Oxford: Oxford University Press, 2009).

57 In the context of global administrative law, the main interlocutors often cite to Bhupinder Chinmni's work on global administrative law. This reference simply acknowledges that there are scholars like Chimni that challenge the central assertions of global administrative law from the perspective of the Third World. For a recent example, see Stewart, "Normative Dimensions", supra note 11 at 499.

58 With the exception of Oklopcic, supra note 6; Peer C Zumbansen, "The Incurable Constitutional Itch: Transnational Private Regulatory Governance and the Woes of Legitimacy" in Michael Helfand, ed, The Challenges of Global and Local Legal Pluralism: Mediating State and Non-State Law (Cambridge: Cambridge University Press, 2014).

59 Richard Delgado, "The Imperial Scholar Revisited: How To Marginalize Outsider Writing, Ten Years Later" (1992) 140 U Pa L Rev at 1352 [Delgado, "Imperial Scholar"]. 
constitutionalism, there is a reluctance to even acknowledge the presence of Third World-based scholarship. $^{60}$

The final rule, that of the Effective Operator - indicates that, when compared to their Global South counterparts, the institutions and the academic communities of the Global North are much better equipped and trained to make use of legal knowledge. An illustrative example is the role of western experts in international law and its institutions. ${ }^{61}$ As I have argued elsewhere, western experts dominate the field of international criminal law. ${ }^{62}$ These international criminal law experts move quickly from one tribunal to another, taking with them their particular set of expertise. ${ }^{63}$ Their good intentions, however, are clouded by the known unknowns. ${ }^{64}$ These known unknowns are characterised as a "lack of local knowledge of post-conflict settings, whether that is knowledge of the local legal system, local facts, local culture or any other relevant information". ${ }^{65}$ Building on from my earlier claims then, international institutions, especially within the international criminal context, privilege western experts to the detriment of the local experts, which then reinforces Bonilla's effective operator rule. More importantly, international criminal law and its institutions are often identified as an exemplary illustration of global constitutionalism. ${ }^{66}$

It is clear that Bonilla's contributions signify a number of important observations about global administrative law and global constitutionalism. The first rule, the Well of Production, is visible in the discussions on accountability of international law and its institutions. Even though there are significant overtures to include scholars from the Global South (especially in terms of their physical presence in edited collections, journal articles, and conferences ${ }^{67}$ ), the current field of global governance theory vis$\grave{a}$-vis international law and its institutions can be characterised as devoid of contextual analysis from the perspective of the Global South. ${ }^{68}$ For example, there is an assumption that Northern scholars' cursory

60 For a recent example, see Bardo Fassbender \& Anne Peters, "Introduction: Towards A Global History of International Law" in Bardo Fassbender et al, eds, The Oxford Handbook of the History of International Law (Oxford: Oxford University Press, 2014) at 2 [Fassbender, "History"].

61 Galit Sarfaty, "Why Culture Matters in International Institutions: The Marginality of Human Rights at the World Bank" (2009) 1033:4 AJIL 647; Elena A Baylis, "Tribunal-Hopping with the Post-Conflict Justice Junkies" (2008) 10 Or Rev Intl L 361; Xavier, "Response to Ladeur", supra note 17.

62 Xavier, "Response to Ladeur", supra note 17; Sujith Xavier, "Looking for 'Justice' in all the Wrong Places: An International Mechanism or Multidimensional Domestic Strategy for Mass Human Rights Violations in Sri Lanka?” in Amarnath Amarasingam \& Daniel Bass, eds, Post-War Sri Lanka: Problems and Prospects (New York: Hurst University Press, 2015) [Xavier, "Looking for 'Justice'”].

63 Baylis, supra note 61.

64 Ibid at 383.

65 Xavier, "Response to Ladeur", supra note 17.

66 Axel Marschik, "Legislative Powers of the Security Council" in Ronald St. John Macdonald \& DM Johnston, eds, Towards World Constitutionalism: Issues on the Legal Ordering of the World Community (Leiden: Martinus Nihjoff, 2005) 457 at 461-72.

67 Chimni, "Co-option", supra note 6.

68 A good example is the global administrative law casebook and the Palestinian bid for statehood. One of the authors included in the casebook suggests that the Palestinian bid for statehood before the ICC is an indicia of global administrative law. Such a suggestion is naïve, to say the least. It ignores the context of the Palestinian bid for statehood. Palestinian claims to statehood can be traced back to the Mandate of the League of Nations, and Arab Israeli conflict 
top-down view of how international institutions operate may capture how these international institutions function in their respective places, such as the International Criminal Tribunal for Rwanda's operations in Arusha, Tanzania. This argument reinforces Bonilla's positing that the "only context for the production of knowledge is the legal academia in the North" ${ }^{69}$ By ignoring the relevant discussions about the Global South, including the critical insights of the subaltern studies movement ${ }^{70}$ and its progenies, ${ }^{71}$ there is a reliance on the "Well of Production" rule in global governance theories. ${ }^{72}$

The second and third rules - "Protected Designation of Origin"73 and "Effective Operator", - are very much present in discussions about international law and its institutions. We can discern that Northern legal knowledge production is worthy of respect and recognition "per se, given the context from which it emerges". 75 This can be illustrated by the failures of global administrative lawyers and global constitutionalism scholars to incorporate critical insights from and about the Global South. ${ }^{76}$

Relying on Bonilla's scholarship, it is clear that the current state of global governance theory, especially global constitutionalism and global administrative law, is replete with shortcomings. While not an exhaustive account, this analysis forms the backdrop to the central issues being pursued in this paper: should we learn from the Global South and how can we learn from the Global South? In the following sections, I take up these two questions respectively.

\section{THEORISING GLOBAL GOVERNANCE FROM THE GLOBAL SOUTH?}

With the above framing, this section of the paper further examines scholarly interventions that suggest we should turn to the Global South as a site of knowledge production. In answering the

starting in 1948; Yoav Meer, "The Notion of State: The Palestinian's National Authority's Attempt to Bring a Claim in Front of the International Criminal Court Against Israel" in Cassese, supra note 15 at 47-51.

69 Bonilla, "Introduction", supra note 32 at 9.

70 There are various schools of thought within the subaltern studies movement. Scholars writing under the broad umbrella of subaltern studies movement include: Ranajit Guha, History at the Limit of World-History (New York: Columbia University Press 2002); Ranajit Guha, Elementary Aspects of Peasant Insurgency in Colonial India (Durham: Duke University Press, 1999); Dipesh Chakrabarty, Provincializing Europe: Postcolonial Thought and Historical Difference (Princeton: Princeton University Press, 2000); Gayatri Chakravorty Spivak, "Can the Subaltern Speak?" in Cary Nelson \& Lawrence Grossberg, eds, Marxism and the Interpretation of Culture (Chicago: University of Illinois Press, 1988) at 271-313.

71 See scholarship on TWAIL: Antony Anghie \& BS Chimni, "Third World Approaches to International and Individual Responsibility in Internal Conflicts" (2003) 2:1 Chinese J Intl L Law 71; BS Chimni, "The World of TWAIL: Introduction To the Special Issue" (2011) 3:1 Trade, L \& Development 14 at 20 [Chimni, "Introduction to Special Issue"]; James Gathii, "TWAIL: A Brief History of its Origins, its Decentralized Network, and a Tentative Bibliography" (2011) 3:1 Trade, L \& Development 26; But see Karin Mickelson, "Taking Stock of TWAIL Histories," (2008) 10 Intl Community L Rev 355 [Mickelson, "Taking Stock”].

72 See Xavier, False Universalisms, supra note 7.

73 "This indicates that all knowledge produced in the North is worthy of respect and recognition per se, given the context from which it emerges"; Bonilla, "Introduction," supra note 32 at 10.

74 "This rule indicates that academics and legal institutions from the North are much better trained to make effective and legitimate use of legal knowledge than academics and legal institutions from the South." Ibid at 11.

75 Ibid at 8-10.

76 For a similar claim in the American domestic context, see Delgado, "Imperial Scholar", supra note 59 at note 2. 
question; should we turn to the Global South, I will focus on the writings of various scholars from different fields including anthropology, sociology and international law. What is certain is that there is a clear body of literature that calls for a reorientation towards the Global South as means to transcend the Eurocentricity of western social science.

Once I have explored the claims, then the analysis will lead into an examination of the reconstructive elements embedded in TWAIL. Over the past 20 years, TWAIL scholars have sought to critically evaluate international law and its institutions. Unfortunately, these interventions have not had significant influence in global governance theory, ${ }^{77}$ in particular, global administrative law or global constitutionalism. ${ }^{78}$ Accordingly, I use this space to examine the diverse arguments housed under the moniker of TWAIL in order to understand its reformist agenda and to embed it within conversations on global governance.

\section{A. Interdisciplinary Reorientation towards the Global South}

Contemporary interdisciplinary scholarship has built upon a tradition of critique by questioning how the empire speaks to, and speaks about, the metropole. Anthropologists have been actively calling for a reorientation towards the Global South. In this vein, Jean and John Comaroff's 2012 Theory From The South is a text rich in ideas. They start by noting that western enlightenment has "posited itself as the wellspring of universal learning, of Science and Philosophy, upper case". ${ }^{79}$ Western englightment simultaneously has characterised its other, the Global South "as a place of parochial wisdom, of antiquarian traditions, of exotic ways and means. Above all, of unprocessed data. These other worlds, in short, are treated less as sources of refined knowledge than as reservoirs of raw fact" ${ }^{80}$ Comaroff and Comaroff further sugget that in combating the eurocentrism of the various disciplines, we should invert the order of things:

But what if, and here is the idea in interrogative form, we invert that Order of Things? What if we posit that, in the present moment, it is the so-called 'Global South' that affords privileged insight into the workings of the world at large? That it is from here that our empirical grasp of its lineaments, and our theory-work in accounting for them, ought to be coming, at least in major part? ${ }^{81}$

77 Fassbender, "History", supra note 60 at 2; A recent exception to the rule is Oklopcic, supra note 6 at 203. A similar question was raised by Critical Race Scholars in the United States in the early 1980s; see for example Richard Delgado, “The Ethereal Scholar: Does Critical Legal Studies Have What Minorities Want?" (1987) 22 Harv CR-CLL Rev 301; Richard Delgado, "Critical Race Theory: An Annotated Bibliography" (1993) 79 Va L Rev 461 at 461.

78 Bonilla, "Introduction", supra note 32 at 11; But see Peer Zumbansen, "Defining the Space of Transnational Law: Legal Theory, Global Governance \& Legal Pluralism” (2012) 21:1 Transnat'1 L \& Contemporary Probs 305; Peer Zumbansen, "Comparative, Global and Transnational Constitutionalism: The Emergence of a Transnational Legal-Pluralist Order" (2012) 1:1 Global Constitutionalism 16; Peer Zumbansen, starting with his Transnational Legal Pluralism article, has argued that global governance scholarship must take TWAIL scholarship seriously. Comaroff \& Comaroff, supra note 32 at 1.

80 Ibid.

81 Ibid. 
Their proposal to "invert the order of things" is based on the realisation that contemporary actors, norms, and processes are reconfiguring our understandings of the core-and-periphery. Because of the processes of globalisation, the Global South is experiencing "some of the most innovative and energetic modes of producing value" and this is the "driving impulse of contemporary capitalism as both a material and cultural formation". ${ }^{82}$ Whether it is to mine mineral resources ${ }^{83}$ or sew shirts, it is an accepted fact that most materials are now produced cheaply and quickly in the Global South. Moreover, various modes of governance techniques are being deployed in the Global South. In order to grasp the history of the present, both empirically and theoretically, Comaroff and Comaroff suggest that we must study the Global South. ${ }^{84}$ As the acceleration of the various modes of production by different actors, processes, and norm generators expand, it is the Global South that is experiencing these repercussions first. This insight is invaluable for the current purpose of how we theorise global governance. As international lawyers like David Kennedy have suggested, the Global South is where the global governance rubber hits the road. ${ }^{85}$

As seen from the discussion about the meaning of the Global South, scholars have theorised the Eurocentricity of modernity beyond the field of anthropology. ${ }^{86}$ Suggestions emerging out of the field of anthropology are similar to proposals by scholars such as Santos and Connell who to turn to the Global South as a site of knowledge production. Connell, whose interventions have been characterised as an attempt at global sociology ${ }^{87}$, has turned to southern theory by examining specific locations in the Global South and tracing the social theorising therein. Santos too has called for greater espistemologies of the South. ${ }^{88}$

Ultimately, these interdisciplinary contributions suggest that we should learn further from the Global South. Even within the field of international law, Third World scholars have been calling for a turn to the Global South through networks like Third World Approaches to International Law.

\section{B. Third World Approaches to International Law [TWAIL]}

TWAIL's origins can be attributed to an emergence of both reactive and proactive scholarship against the various colonial and imperial projects of international law. The first ever TWAIL conference was organised at Harvard Law School in $1997 .{ }^{89}$ The movement has since grown, and now includes scholars from diverse disciplines and locations. Accordingly, there have been a number of conferences, with the most recent taking place in 2015 in Cairo, Egypt. Given the origins of its first conference, TWAIL's

$82 \quad$ Ibid at 22.

83 Charis Kamphuis, "Foreign Investment and the Privatization of Coercion: A Case Study of the Forza Security Company in Peru" (2011-2012) 37 Brook J Intl L 529; Edward Bearnot, "Bangladesh: A Labor Paradox" (2013) 30:3 World Policy Journal 88.

84 Comaroff \& Comaroff, supra note 32 at 7, 117.

85 David Kennedy, "Mystery of Global Governance" in Jeffrey L Dunoff \& Joel P Trachtman, eds, Ruling the World; Constitutionalism, International Law, and Global Governance (Cambridge: Cambridge University Press, 2009 ) at 41.

$86 \quad$ Bhambra, supra note 31; Subrahmanyam, supra note 36.

87 Bhambra, ibid at 97.

88 Santos, Epistemologies, supra note 33.

89 A draft of the memo of the conference invitation is on file with the author; Gathii, supra note 71. 
foundations are rooted in critical scholarship, especially US legal realism, critical legal studies, feminism and critical race theory. ${ }^{90}$ TWAIL's origins can also be located in postcolonial theory. ${ }^{91}$

Historically, TWAIL scholars have themselves identified two generational moments in the development of TWAIL scholarship. ${ }^{92}$ This type of periodization however is susceptible to challenges. ${ }^{93}$

TWAIL can be characterised as an anti-hierarchical counter-hegemonic coalitionary movement that is deeply suspicious of universal creeds and truths. ${ }^{94}$ It is anti-hierarchical because it challenges the Eurocentricity of the history of international law and continued propagation of particular monolithic universal values therein. These include specific claims to global administrative law and global constitutionalism as universal creeds. ${ }^{95}$ In a subversive turn, TWAIL scholars suggest a dialogic maneuver across cultures. TWAIL calls for the recognition of existing inequities within the structures of international law. It also calls for the recognition of the subaltern voices and demands that all voices be represented. ${ }^{96}$

Broadly, the movement's unifying raison d'être is to: "challenge the hegemony of the dominant narratives of international law, in large part by teasing out encounters of difference along many axesrace, class, gender, sex, ethnicity, economics, trade etc. - and in inter-disciplinary ways - social, theoretical, epistemological, ontological and so on". ${ }^{97}$ By challenging these dominant narratives, TWAIL seeks to "reduce the distance of the world of international law from the lives of ordinary peoples". ${ }^{98}$

Makau W. Mutua formulated TWAIL's three central tenets in $2000 .{ }^{99}$ The first is to understand, deconstruct, and unpack the uses of international law as a medium for the creation and perpetuation of a racialised hierarchy of international norms and institutions that sub-ordinate non-Europeans and Europeans alike. ${ }^{100}$ Contemporary TWAIL scholarship can be grouped under the auspices of these tenets. The second component of TWAIL is much more prescriptive in that it seeks to create alternative normative legal edifices for international governance. This is what I hope to achieve in this article. Third, through policy scholarship, TWAIL scholars aim to eradicate the conditions of underdevelopment in the Global South (through praxis for example). ${ }^{101}$ This reformist agenda presents a natural opportunity for building bridges between conceptions of global governance and critical insights about the Global South.

$90 \quad$ Ibid at 28.

91 Frantz Fanon, Black Skin, White Masks, translated by Richard Philcox (New York: Grove Press, 2008); Frantz Fanon, The Wretched of the Earth, translated by Richard Philcox (New York: Grove Press, 2004); Edward W Said, Orientalism (New York: Random House, 1979); Achille Mbembe, On the Postcolony (Berkeley: University of California Press, 2001).

92 Gathii, supra note 71 at 14; Anghie \& Chimni, supra note 71.

93 Mickelson, "Taking Stock", supra note 71; George Galindo, "Splitting TWAIL" (2016) 33 Windsor YB Access Just 37.

94 Makau Mutua, "What is TWAIL?" (2000) 94 Am Society Intl L Proceedings 31 [Mutua, "What is TWAIL"].

95 Xavier, "Response to Ladeur", supra note 17.

96 Mutua, "What is TWAIL", supra note 94; Antony Anghie, "What is TWAIL: Comment" (2000) 94 Am Soc Intl Proc 39.

97 Gathii, supra note 71 at 37.

98 Chimni, "Introduction to Special Issue", supra note 71 at 20.

99 Mutua, "What is TWAIL", supra note 94.

100 Ibid.

101 Ibid. 
A number of scholars are using the reformist elements of TWAIL. The fundamental task of these scholars is to articulate the emancipatory ideals housed in international law. These overtures are analogous to the arguments deployed by earlier TWAIL scholars, who called for the emancipation of the former colonies using international law. ${ }^{102}$

Nevertheless, compelling arguments from these international law scholars have not garnered much influence on substantive reforms or within theoretical debates. For example, in the fields of international criminal law and transitional justice, TWAIL scholars are quite active in describing the problematic nature of prosecutions of international criminal institutions, ${ }^{103}$ polemics of transitional justice, ${ }^{104}$ or sole focus of prosecution by the International Criminal Court in Africa. ${ }^{105}$ Such projects reinforce the claim made in 1983 by the first Tanzanian President Julius Nyerere that "[i]n international rule making, we [the Third World] are recipients not participants". ${ }^{106}$ Given the inequities perpetuated by the on-going proselytisation of western values, there is a need to interrupt this narrative and reimagine a better future. This is a future that includes the various places and peoples of the Global South as both recipients and active participants in international law and its theories.

Critics of TWAIL allude to its potential for nihilism. ${ }^{107}$ The charge of nihilism is predicated on TWAIL scholars' critical position towards international law. These claims of nihilism ignore TWAIL's reformist aims. It is precisely these neglected reformist aims that I seek to excavate and place in conversations with global governance theorising. In this regard, analogous to the other disciplines and other fields of law that I discussed earlier in this section, TWAIL too calls for a reorientation towards the Global South. The reformist elements housed within TWAIL are part of this reorientation and I will elaborate on these claims in the following sections.

There is another line of criticism that has centred on the Marxist tradition. Robert Knox argues that TWAIL scholarship is wedded to liberal legalism. ${ }^{108}$ Using the idea of principled opportunism, ${ }^{109} \mathrm{Knox}$ suggests that TWAIL, and critical scholarship in general, must now rethink its efforts to achieve

102 Anghie \& Chimni, supra note 71 at 80.

103 Makau W Mutua, "Africa and the International Criminal Court: Closing the Impunity Gap", The Broker Magazine (7 December 2010) [Mutua, "Closing the Impunity Gap"]; Kamari Maxine Clarke, Fictions of Justice: The International Criminal Court and the Challenge of Legal Pluralism in Sub-Saharan Africa (Cambridge: Cambridge University Press, 2009) [Clarke, Fictions of Justice]; Tim Kelsall, Culture Under Cross-Examination: International Justice and the Special Court for Sierra Leone (Cambridge: Cambridge University Press, 2009).

104 Vasuki Nesiah, "The Trials of History: Losing Justice in the Monstrous and the Banal" in Ruth Buchanan \& Peer Zumbansen, eds, Law in Transition: Human Rights, Development and Transitional Justice (Portland: Hart, 2016).

105 Mutua, "Closing the Impunity Gap", supra note 103.

106 Mutua, "What is TWAIL", supra note 94 at 30.

107 Jose Alvarez, "My Summer Vacation Part II: Revisiting TWAIL in Paris" (29 September 2010), Opinio Juris (blog), online: <http://opiniojuris.org/2010/09/28/my-summer-vacation-part-iii-revisiting-twail-in-paris/>; David P Fidler, "Revolt Against or From Within the West? TWAIL, the Developing World, and the Future Direction of International Law" (2003) 2:1 Chinese J Intl L 29.

108 Robert Knox, "Strategy and Tactics" (2012) 21 Finnish YB Intl L 193.

109 Knox defines institutional aspects of "principled opportunism" as: "[D]emands that the deployment of legal argument be openly subjected to political exigencies, with divergent arguments being deployed whenever necessary. As such, legal argument is being geared towards the strategic aim of building a movement to overthrow capitalism, rather than on its own terms. On the one hand, this will involve defensive struggles, where legal argument is deployed in order to defend political activists when the state seeks to attack them"; Ibid at 224. 
systemic change. His fear is that by focusing on immediate concerns, TWAIL scholars lose track of the larger strategy. Those committed to a better world end up confusing the current tactic for immediate gains with the overall strategy of broader systemic change. ${ }^{110}$ Knox is absolutely correct in his observation. This paper is written in this tradition of trying to move beyond the immediate tactics that Knox is critical of, to one where we can theorise global governance from the vantage point of the Global South and usher in participation of the various stakeholders in the Global South.

Having identified a variety of perspectives that argue in favour of a reorientation towards the Global South and setting out TWAIL's foundational pillars, I will now elaborate on TWAIL's prescriptive components as it relates to the question: how can we learn from the Global South in theorising global governance?

\section{RESISTANCE AND RENEWAL: HOW TO LEARN FROM THE GLOBAL SOUTH?}

While current TWAIL literature can be categorized as a form of resistance, it is also important to remember the suggestions for reform. ${ }^{111}$ As referenced earlier, the first tenet of TWAIL is to deconstruct and unpack the existing hierarchies within international law and its institutions. The current TWAIL literature, written in this genre, seeks to challenge western universalism in particular.

A small number of contemporary academics are working on reformative projects under the auspice of TWAIL. These projects seek to redeem international law's promise. ${ }^{112}$ These writers have sought to harness the emancipatory power of international law. Not entirely dissimilar to their predecessors, academics working under the more contemporary umbrella of TWAIL are hopeful of international law's potential and do not reject international law altogether. ${ }^{13}$ These scholars argue for a reconstruction of international law in a manner that reflects the concerns of the Global South. ${ }^{114}$

One such example is the scholarship of Balakrishan Rajagopal. Even though he recognizes that such attempts may render minimal results, ${ }^{115}$ he suggests that it is "legitimate to use international law as an explicit counter-hegemonic tool of resistance". ${ }^{116}$ The current TWAIL scholarship is hopeful that international law can realise its emancipatory potential. An illustration of this hopefulness is apparent in Antony Anghie's writing:

110 Ibid.

111 Luis Eslava \& Sundhya Pahuja, "Between Resistance and Reform: TWAIL and the Universality of International Law" (2012) 3:1 Trade, L \& Development 103 at 110 [Eslava \& Pahuja, "Between Resistance and Reform"].

112 Scholars working on Critical Race Theory make similar moves. For example, Patricia Williams has characterised this belief (vis-à-vis rights) as: "Rights" [international law, international criminal law etc.] feels new in the mouths of black people. It is still deliciously empowering to say. It is the magic wand of visibility and invisibility, of inclusion and exclusion, of power and no power"; Patricia J Williams, The Alchemy of Race and Rights (London: Virgo Press, 1993) at 164.

113 Ruth Buchanan, "Writing Resistance into International Law" (2008) 10 Intl Community L Rev 445; Richard Falk, Balakrishnan Rajagopal \& Jacqueline Stevens, International Law and the Third World: Reshaping Justice (New York: Rutledge-Cavendish, 2010).

114 Balakrishnan Rajagopal, "Counterhegemonic International Law: Rethinking Human Rights and Development as a Third World Strategy” (2006) 27:5 Third World Q 767 [Rajagopal, "Counterhegemonic”]; Falk, Rajagopal \& Stevens, Ibid.

115 Buchanan, supra note 113 at 453-454.

116 Rajagopal, "Counterhemonic", supra note 114 at 772. 
I continue to hope, together with the many scholars who are working to reconstruct international law precisely because of their awareness of the many ways in which it has operated to exclude and subordinate people on account of their gender, race and poverty, that international law can be transformed into a means by which the marginalized may be empowered. In short, that law can play its ideal role in limiting and resisting power. At the very least, I believe that the Third World cannot abandon international law because law now plays such a vital role in the public realm in the interpretation of virtually all international events. ${ }^{117}$

Even though the hopefulness expressed by Anghie and other TWAIL scholars has been the subject of a recent debate, ${ }^{118}$ it is certain that there are at least two potential prescriptive claims that we can discern in answering the question of how can we learn from the Global South in theorising global governance.

The first claim, forged as a response to TWAIL's flirtations with monism ${ }^{119}$, is to take stock of international law as a field of practice and to expand ethnographic research that is committed to a TWAIL-based ideology. Here the argument centres on the potential use of ethnography as a means to study the field of international law from the perspective of the Global South and to provide insights into how global governance mechanisms affect the daily-lived realities of the people of the Global South. ${ }^{120}$

The second centres on the ethical duty of international lawyers and international law scholars to contend with the material reality of the Global South. In this section I argue that as intellectuals, international lawyers and international law scholars we have an ethical responsibility to articulate accurate portrayals of global governance initiatives and its effects on the lives of the people of the Global South.

\section{A. International Law as a Field of Practice}

Some writers believe that while TWAIL scholars engage in thoughtful political arguments that lead them to the edge of the abyss, they are nonetheless unable to go beyond the precipice because they are

117 Anghie, Imperialism, supra note 23 at 318.

118 Buchanan, supra note 113 at 454; Buchanan focuses on the idea of hopefulness in the scholarship of Rajagopal and Nesiah. She suggests the following:

"My suspicion is that there is something in the professional commitment of international lawyers, no matter how critical, that obscures the limits of their own (internal) critiques. While the deeply thoughtful and political arguments of scholars such as Nesiah and Rajagopal lead them right up to the edge of the abyss (the limits of law itself), they are unwilling or unable to envision the next step. Part of this suspension might be premised on an implicitly monist understanding of law that stands in the way of a meaningful engagement with the legal pluralism that many TWAIL scholars nonetheless recognise as necessary. Part of it may also have to do with the necessity of theorising the 'event', that is, the need to address the usually unspoken question about the relationship between law, force and revolution. And finally, much of this productive tension might be seen to derive from the dueling commitments embraced by these Third World international legal scholars whose work is illuminating precisely because it refuses the usual comfortable resting places.

119 Monism is the belief that international law, made through international relations, must be brought home through sovereign enactment by way of domestic governments.

120 Luis Eslava, Local Space, Global Life: The Everyday Operation of International Law and Development (Cambridge: Cambridge University Press, 2015) [Eslava, Local Space]. 
wedded to monist understandings of law. ${ }^{121}$ Luis Eslava and Sundhya Pahuja make the argument that, for TWAIL scholars, international law's promise resides in its universality, nothwithstanding their very own critique that international law carries with it its own particularities. ${ }^{12}$ The belief in the promise of international law, they suggest, is a circular argument. Eslava and Pahuja suggest: "Such an attempt would be to engage in a neo-Kantian enterprise of finding a new, genuinely universal ground for law. TWAIL's concern for history has shown us repeatedly that these ostensibly genuine universals invariably end up elevating a particular meaning to the universal [...]". ${ }^{123}$

Eslava and Pahuja's intervention signals a warning to TWAIL's reformist agenda. What we can gather from their analysis is rather prescriptive. They hint that TWAIL's political project calls for the recognition of a universality. To them, it is a normative conception of international law's promise of universalism and they see it as being "quasi-transcendent". ${ }^{24}$ There is no material reality at the moment in which to achieve emancipation as a result of TWAIL's criticisms. Such recognition gives way to the potential of plurality. In effect, they posit a moving away from monist conceptions of international law to one that envisions international law as a domain of practice. ${ }^{125}$

In this imagining, we are able to rely on international law's specific procedures, "artefacts and forms of being that operate at the mundane and quotidian level and that tie together a vast raft of heterogeneous phenomena in a specific kind of way". ${ }^{126}$ TWAIL's body of scholarship has already identified political, cultural and economic biases buried deep within the structure of international law. Eslava and Pahuja's approach would shed light on how these embedded vernaculars affect the day-today lives of those that must confront the effects of international law. ${ }^{127}$

In a similar vein, Obiora Okafor argues that TWAIL is a theory and method. ${ }^{128}$ This proposal seriously pushes for a methodological shift that echo's the concerns of others scholars like Eslava and Pahuja and I adopt this perspective. Thinking about TWAIL as a method and a theory "build[s] explicitly on the legal-ethnographic method currently being applied explicitly in international sites and artefacts such as international criminal courtrooms or international NGOs". ${ }^{29}$ Eslava and Pahuja call for an ethos of ethnography as TWAIL's new unexplored frontier in which scholarship seeks to identify embedded biases in multiple registers. This suggestion to conduct more ethnographies is a general claim

121 Buchanan, supra note 113 at 454.

122 Eslava \& Pahuja, "Between Resistance and Reform", supra note 111 at 121.

123 Ibid.

124 Ibid at 122.

125 "The turn away from monism of international law is not novel. This approach can be 'discovered' in the recent scholarship of transnational legal pluralism that focuses on the actors, norms and processes. The scholars working under transnational legal pluralism build on Jesup's transnational law and they re-characterize the public/private distinctions. Transnational legal pluralism draws inspirations from the insights of decentering the primacy of public-private distinctions and they build on the observations that law need not be formulated through sovereign power, rather law can emanate from diverse set of actors". Ibid at 125

126 Luis Eslava and Sundhya Pahuja, "Beyond the (Post)Colonial: TWAIL and the Everyday Life of International Law" (2012) 45:2 J of L and Politics in Africa, Asia and Latin-America - Verfassung und Recht in Übersee (VRÜ) 195 at 213.

127 Eslava, Local Space, supra note 120.

128 Obiora C Okafor, "Critical Third World Approaches to International Law (TWAIL): Theory, Methodology, or Both?" (2010) 10 Intl Community L Rev 37.

129 Eslava \& Pahuja, "Between Resistance and Reform", supra note 111 at 126. 
with an understanding that there are multiple types of ethnographies in various institutions and normproducing spaces.

Ethnography as a general field of study is intricately connected to social sciences like anthropology and sociology. It is a method of study deployed by social scientists, including legal scholars. It is generally understood as the study of people in "naturally occurring settings or 'fields' by methods of data collection which capture their social meanings and ordinary activities, involving the researcher participating directly in the setting". ${ }^{130}$ The purpose is to collect data in a systematic fashion without externally imposing meaning. ${ }^{131}$

Ethnography, an anthropological method, was the handmaiden of colonialism and imperialism. ${ }^{132}$ At its inception, it was used as a means to track and study the Indigenous populations of the newly discovered world by various colonisers. ${ }^{133}$ This field of study has evolved, integrating insights from various disciplines and theoretical positions, including postmodernism and colonialism. ${ }^{134}$ In particular, there is a burgeoning sub-field of critical ethnography that focuses on power relations and effective systemic changes "toward greater freedom and equity". ${ }^{135}$

Most recently, Mohawk scholar Audra Simpson has added another layer to the discussions about ethnography that is premised on the politics of refusal. This is important when thinking about ethnography as a potential tool in learning how to theorise global governance from the perspective of the Global South. Simpson coins her intervention the "cartography of refusal," which requires an acknowledgment of the role of ethnography in constructing and defining Indigenous groups and their politics. ${ }^{136}$ In describing this refusal, Simpson notes:

These conditions [imperialism and settler colonialism and the role of law and anthropology in constructing Indigenous identity] have led to this book as an ethnography that pivots upon refusal(s). I am interested in the larger picture, the discursive, material and moral territory that was simultaneously historical and contemporary (this "national" space) and the ways in which Kahnawa'kehró:non had refused the authority of the state at almost every turn and in doing so instantiated a different political authority. [...]

There is no place in the existing literature for these articulations; nor is there now a neat placement for them within postcolonial studies or analysis. Kahnawa'kehró:non were not free from occupation, which naturalized as immigration, as multiculturalism, and was and is a legalized, settler occupation of the territory that they claim. Thus there was no

\footnotetext{
130 John Brewer, Ethnography (Buckingham: Open University Press, 2000) at 6.

131 Ibid.

132 Ibid at 11.

133 Audra Simpson, Mohawk Interruptus (Political Life Across Borders of Settler States) (Durham: Duke University Press, 2014) at 33.

134 Robin Patric Clair, "The Changing Story of Ethnography" in Robin Patric Clair, ed, Expressions of Ethnography Novel Approaches to Qualitative Methods (Buffalo: SUNY University Press, 2003).

135 Soyini Madison, Critical Ethnography Method, Ethics, and Performance, 2nd ed (New York: Sage Publication, 2012) at 5.

136 Simpson, supra note 133 at 33.
} 
doubleness to their political consciousness, a still-colonial but striving-to-be "postcolonial consciousness," that denied the modern self, which Frantz Fanon, Homi Bhabha, and Anthony Giddens speak of and from [...]. Here I want to push "turning away" into the ambit of refusal - of simply refusing the gaze of disengagement - and to the possibilities that this structures: subject formation, but also politics and resurgent histories. In my ethnographic work I was deeply mindful of the range of possibilities available for political life, for identification and identity within and against recognition, all instantiated in refusals. There seemed, rather, to be a tripleness, a quadrupleness to consciousness and an endless play, and it something like this: I am me, I am what you think I am, I am who this person to the right of me thinks I am, and you are all full of shit, and then maybe I will tell you to your face and let me tell you who you are. ${ }^{137}$

This new layer adds further nuance to the study of ethnography. Simpson's suggestion has a significant amount of potential for future TWAIL-based ethnographies about the material reality of the people of the Global South. Not only does she suggest that there are distinctions between the concerns of the people of the Global South and Indigenous communities, Simpson posits the idea of using ethnography as both a form of resistance and as a tool of emancipation. These critical insights about ethnography must be taken into account and included in any turn to empiricism, especially ethnography, as a method to learn from the Global South.

We must return to Eslava and Pahuja's suggestion for further empirical and ethnographic scholarship in international law with an understanding that this field of study is multifaceted with its own boundaries. More importantly, the call for ethnographic research and empirical studies is not new. Rather it is part of a rich history in interrogations imbedded in critical approaches to law. Social scientists too have contributed to our understanding of law from varying disciplines utilising different methods. This type of turn to empiricism in law is also not new. It can be traced back to the early 1900s. ${ }^{138}$

The move towards ethnographies from the Global South as a means to theorise global governance is, I argue part of TWAL's reformist agenda. This turn to empiricism does offer us the potential to map the existing material reality, relying on data collected based on observations of the everyday in places like Palestine, Sri Lanka, South Africa and other such locations. These observations can capture the social meanings of everyday occurrences in international law and its institutions. There are a handful of examples of scholars who have provided such analysis. ${ }^{139}$ For instance, Luis Eslava has undertaken an

\footnotetext{
Ibid at 106-107.
}

138 Oliver Wendell Holmes, "The Path of the Law" (1897) 10 Harv L Rev 457; Sally Falk Moore, "Law and Social Change: the semi-autonomous field as an appropriate subject of study" (1973) 7 Law \& Soc'y Rev 719; Marc Galanter, "Justice in Many Rooms: Courts, Private Ordering and Indigenous Law" (1981) 19 J Leg Pluralism; John Griffiths, "What is Legal Pluralism" (1986) 24 J Leg Pluralism 1.

139 Galit A Sarfaty, "Measuring Justice: Internal Conflict over the W'rld Bank's Empirical Approach to Human Rights" in Kamari Clarke \& Mark Goodale, eds, Mirrors of Justice: Law and Power in the Post-Cold War Era (Cambridge: Cambridge University Press, 2009); Annelise Riles, "Models and Documents: Notes on Some Artifacts of International Legal Knowledge" (1999) 48 Intl and Comparative L Q 809; Clarke, Fictions of Justice, supra note 103; Kelsall, supra note 103. 
ethnographic analysis of international development policies in changing the internal dynamics of Bogota, Colombia. ${ }^{140}$ But we need more such scholarship, especially as it relates to lived realities of the people of the Global South and how global governance mechanisms affect their daily lives.

The complexity of conducting ethnographic work is elevated when theorising global governance from the perspective of the Global South. We must contend with this complexity and should heed Audra Simpson's warnings. Taking stock of the work of critical ethnographers and the interventions by Simpson, there is a need to engage in this type of scholarship with a commitment to the politics of the Global South. Much more importantly, in undertaking this type of work, scholars must engage with, and be aware of the politics of recognition ${ }^{141}$ and the politics of refusal. ${ }^{142}$ The politics of recognition centre on the possibility of engaging the contemporary western legal orders as a means to make material changes. ${ }^{143}$ Ultimately the moves to engage any colonial structure will undoubtedly reinforce the "colonial state power" (both actual and symbolic). ${ }^{144}$

The politics of refusal is centred on the resistance to the settler colonial endgame - the elimination of the Indigenous identity. It is about the possibility of surviving, resisting and refusing. ${ }^{145}$ Interestingly, the politics of refusal signals the possibilities of living and resisting without engaging in practices that lead to subjugation brought about by colonialism and imperialism in socities in the Global South and in settler nations.

What we can learn from Eslava and Pahuja's articulation of international law as practice is the need to examine the broader context in which international law and international institutions function. It is necessary to be attuned to the socio-political, cultural and economic factors that surround the examples that are used to denote the legitimacy of international law and its institutions. The exercise of thinking about international law and its institutions as a field of practice shifts our perspective away from one centred on formal international legal mechanisms. By repositioning our attention to the realm of practice, we are able to take note of divergent factors that shape the operationalisation of international norms on the ground, or where the rubber of global governance hits the road. ${ }^{146}$

\section{B. International Lawyers, International Law Scholars and Ethics}

Lassa Oppenheim's suggestion in 1908 - that international lawyers should plough their fields - is still very relevant today. ${ }^{147}$ Within the scholarship about global constitutionalism, global administrative law, public international law, and global governance, international lawyers and international law scholars craft the territorial boundaries of their respective subfields. Much more importantly, these outputs,

\footnotetext{
140 Eslava, Local Space, supra note 120.

141 Glen Sean Coulthard, Red Skins White Masks: Rejecting the Colonial Projects of Recognition (Minneapolis: University of Minnesota Press, 2014) at 25-48.

142 Simpson, supra note 133 at 33.

143 See chapter 3, Xavier, False Universalisms, supra note 7 at 210-213 for a much more robust discussion of global constitutionalism and the politics of recognition.

144 Ibid at 210-213.

145 Simpson, supra note 133 at 11.

146 Kennedy, supra note 85.

147 Lassa Oppenheim, “The Science of International Law: Its Task, Its Method” (1908) 2 AJIL 313.
} 
especially those of learned jurists, are elevated to the status of sources of international law. ${ }^{148}$ The expert opinions of scholars, by way of sources of international law through the ICJ Statute, then become applicable in the everyday practices of the people of the Global South as part of the globalisation of international law through international institutions.

These practical implications about the very nature of international legal practice are analogous to, and bound up in, concerns that domestic practitioners and domestic legal professional regulatory bodies often grapple with. ${ }^{149}$ These implications centre on such questions as: What is the role of the international lawyer and international law scholars in contemporary society? ${ }^{150}$ What are the professional responsibilities and obligations of international lawyers to their clients, and much more importantly, who exactly is their client? What is the significance of the international lawyer or international law scholar's understanding of context in delivering opinion (for example do they have competent understanding of Rwandan history or Yugoslavian politics)?

In this section, I argue that it is important for international lawyers and international law scholars to recognise and be aware of the material and lived realities of the Global South. It is their duty as intellectuals to portray events in a broader context, describing various portions of people that may be differently affected by the manner in which international law and its institutions function. Taking stock of the material lived realities of the people of the Global South is one way to learn from the Global South.

Various legal professions regulate the provision of legal services in national jurisdictions. In the Global South, legal transplants have ushered in professional bodies that are similar to their former colonial masters. ${ }^{151}$ As seen in Sri Lanka, the legal profession is regulated by a law society that functions akin to those found in the United Kingdom, Canada and the rest of the Commonwealth. Domestic legal practitioners have been trained to adopt a specific attitude in how they behave with their clients. $^{152}$ Local lawyers, depending on their respective jurisdictions, are heavily regulated through the respective rules of conduct by their professional bar. A lawyer's professional license is contingent upon ethical behaviour towards the client, the court, the legal community, and the general public.

In the international context, there is no such governing regulatory framework. James Crawford suggests that "[t]here is clearly no international law bar comparable to domestic bars - there are no qualifications which someone must attain before appearing before international courts and tribunals, no international code of ethics with which they must comply, and no international association to sanction

148 Article 38, Statute of the International Court of Justice in Charter of the United Nations, 26 June 1945, Can TS 1945 No 7; James Crawford, Brownlie's Principles of Public Internation ${ }^{\text {al }}$ Law, 8th ed (Oxford: Oxford University Press, 2012) at 367-94.

149 These subsequently arise in how lawyers should behave towards their clients; David M Tanovich, "Law’s Ambition and the Reconstruction of Role Morality in Canada" (2005) 28 Dalhousie LJ 267; David B Wilkins, "Identities and Roles: Race, Recognition, and Professional Responsibility" (1998) 57 Maryland L Rev 1502.

150 Usha Natarajan et al, "Introduction: TWAIL - on praxis and the intellectual" (2016) 37 (11) Third World Quarterly 1946.

151 ARB Amersasinghe, Professional Ethics and Responsibilities of Lawyers (Colombo: Stamford Lake, 2003).

152 Allan Hutchinson, Legal Ethics and Professional Responsibility, 2nd ed (Toronto: Irwin Law, 2006); Tanovich, supra note 149 . 
them for misconduct". ${ }^{153}$ There is only a fragmented set of rules that apply to advocates and counsels before the International Criminal Court, the ad hoc tribunals and other such organisations. ${ }^{154}$ Without reinforcing the liberal legalism imbedded within these professional regulatory regimes, ${ }^{155}$ the questions that fuel this part of the discussion are, to what extent should international lawyers take note of the Global South and its material reality, and do they even have an obligation to do so? Questions such as these underscore the responsibility of international lawyers and international scholars in a regulatory space devoid of formal regulation. ${ }^{156}$

It is important to note the overlap between international lawyers and international law scholars. Throughout this analysis, I have referred to a number of scholars who are both international lawyers and international law scholars. James Crawford is a good example as he is an established academic with a long history of teaching in Australia, the United Kingdom, and other countries. Crawford is also an established international lawyer. He was counsel in a number of leading international law cases before the International Court of Justice. ${ }^{157}$ Crawford was recently appointed to the International Court of Justice. In a similar vein, a number of scholars have demonstrated the connections between the role of specific international lawyers and the development of international law (M. Cherif Bassiouni is a good example). ${ }^{158}$ So, given the fragmented nature of the various standards of conduct and the various roles performed by international lawyers and international law scholars, it may be more useful to think of these individuals, given their overlapping functions, as intellectuals engaged in praxis of international law.

Various writers have theorised the role of intellectuals in our modern society. ${ }^{159}$ Edward Said's contributions are especially significant. Said states: "the principal intellectual duty is the search for

153 James Crawford, “The International Law Bar: Essence Before Existence?” (Paper delivered at the ESIL 2013 5th Research Forum: International Law as a Profession Conference, January 2014), (2014) 3:1 ESIL Conference Paper Series 1 [Crawford, "International Bar"].

154 Philip Sands, "The ILA Hague Principles on Ethical Standards for Counsel Appearing before International Courts and Tribunals" (2011) 10 Law \& Prac Intl Cts \& Trib 14.

155 I recognize that reference to professional rules of conduct is a turn to liberal legalism. See for example, Constance Backhouse, "Gender and Race in the Construction of 'Legal Professionalism': Historical Perspectives" (Paper presented at the First Colloquium on the Legal Profession, October 2003), online:

$<$ http://www.lsuc.on.ca/media/constance_backhouse_gender_and_race.pdf $>$ at 2-13; Wilkins, supra note 149.

156 Crawford, "International Bar", supra note 153.

157 Gabcikovo-Nagymaros Barrage System (Hungary v Slovakia), [1997] ICJ Rep 7 at 7; Legality of the Threat or Use of Nuclear Weapons, [1996] ICJ Rep 226 at 226; Legal Consequences of the Construction of a Wall in the Occupied Palestinian Territory,; [2004] ICJ Rep 136 at 136; Accordance with international law of the unilateral declaration of independence in respect of Kosovo, [2010] ICJ Rep 136 at 136.

158 Martti Koskenniemi, The Gentle Civilizer of Nations: The Rise and Fall of International Law, 1870-1960 (Cambridge: Cambridge University Press, 2001); Antony Anghie, "Vattel and Colonialism: Some Preliminary Observations" in Vincent Chetail and Peter Haggenmacher, eds, Vattel's International Law in a XXIst Century Perspective (The Hague: Martinus Nijhoff, 2011).

159 Antonio Gramsci, The Prison Notebooks, translated by Joseph A Buttigieg (New York: Columbia University Press, 2011) vol 1; Antonio Gramsci, The Prison Notebooks, translated by Joseph A Buttigieg (New York: Columbia University Press, 2011) vol 2; Antonio Gramsci, The Prison Notebooks, translated by Joseph A Buttigieg (New York: Columbia University Press, 2011) vol 3; Edward S Said, Representations of the Intellectual: The 1993 Reith lectures (New York: Vintage Books, 1996) [Said, Representations]. 
relative independence from such [societal] pressures. Hence my characterizations of the intellectual as exile and marginal, as amateur, and as the author of a language that tries to speak the truth to power". 160

The latter point is of particular importance in answering the question: to what extent should international lawyers and international law scholars take note of the Global South and its material reality? ${ }^{161}$ It is important because international lawyers and international law scholars, as intellectuals, are constantly imbricated in milieus of power and authority that shape the lived realities of the people of the Global South. Said suggests that intellectuals should move away from specific specialisation (or as he coins it professionalisation) to the much more accessible attitude of an amateur. ${ }^{162}$

Said helps us move away from an understanding of international lawyers and international law scholars as specialised professionals embarking on their duties by ploughing their respective fields. Rather, Said forces the examination of the material reality of the work that international lawyers and international law scholars undertake in shaping and writing their fields. In effect, this contention requires us to come face to face with those that are directly affected by the laws and policies that are shaped and created by intellectuals working with international law.

Recently, Bhupinder Chimni captured one of the central concerns of TWAIL as part of its reformist agenda: Is human emancipation and environmental protection possible "by altering the material structures or does it require an evolved ethical and spiritual self?" 163 He enquires about the role of international lawyers (and international law scholars) in thinking, and bringing about equitable relations amongst nations states and those that live in these constructed boundaries. ${ }^{164}$

Chimni acknowledges that the Marxist tradition, which he has relied on to deliver his TWAIL-based arguments against international law, is not useful in providing adequate insights for reform. This is especially the case because of the "uneasy experience of actually existing socialism" that we experienced over the years that is rooted in "philosophy of militant materialism as a basis for building a world that expands the realm of human freedom". ${ }^{165}$

Chimni subsequently turns to Gandhi's 1904 Hind Swaraj to find inspiration for some of the central organising tensions embedded in TWAIL. The rationale for this choice is based on the relationship that Gandhi constructs between the self and social transformation as a critique of modern civilisation. Building on Hind Swaraj, Chimni seeks to address Marxism's failings by clarifying the need to be simultaneously "attentive to material structures and to work on the self" ${ }^{166}$ He proposes a number of critical observations that attempt to fill these gaps. By drawing directly from Gandhi, Chimni maps out a number of significant proposals about the state, the grounds for obedience to laws, the understanding of the legal profession and passive resistance. ${ }^{167}$ By reflecting on these important factors, Chimni reveals

\footnotetext{
160 Said, Representations, ibid at xvi.

161 Natarajan, supra note 150.

162 Ibid at $87-88$.

163 BS Chimni, "The Self, Modern Civilization, and International Law: Learning from Mohandas Karamchand Gandhi’s Hind Swaraj or Indian Home Rule" (2012) 23:4 EJIL 1159 at 1160.

164 Ibid at 1160.

165 Ibid.

166 Ibid at 1163

167 Ibid at 1167.
} 
glimpses into alternative global futures, the means by which we can create a better world, and locate the role of international law and international lawyers in that process. ${ }^{168}$

In this regard, I want to hone in on one of the central themes that Chimni identifies in creating a better world - the function and role of international lawyers and by extension international law scholars. ${ }^{169}$ Focusing on this proposal about international lawyers and international law scholars opens up new vistas in imagining various futures from the perspectives of the Global South.

Gandhi's criticisms about the legal profession were based on the role of the courts and lawyers in maintaining and sustaining the colonial rule and the oppression of the people of the Global South. Gandhi's cynicism about the legal profession was precipitated by the disparity between the colonised and colonisers, and the resulting unequal treatment between the European right bearers and nonEuropeans without rights. His cynical views extended further to the belief that the legal profession teaches immorality because lawyers benefit from conflicts that they seek to mediate. Chimni explicates some of these implications for international lawyers and international law scholars with the following:

In my view Gandhi's critique of the legal profession raises crucial issues with respect to the responsibility of international lawyers. I will flag some of them. The first matter relates to the role of the legal adviser to governments. In giving advice should legal advisers privilege truth, read as the global common good and our common humanity, over perceived national interests? Should a legal adviser do a Gandhi to his client if truth were not spoken with regard to the material facts in issue? Secondly, should international lawyers charge exorbitant fees even when that prevents poor individuals and nations from seeking justice? Thirdly, are international lawyers willing to assume personal responsibility for particular interpretations of international law with troubling outcomes for subaltern groups and peoples in the world? Can the ethical self use the legal form as a shield to deflect criticisms? Finally, does a shadow fall between the ideals that often inform the writings of international lawyers and their practices in their professional lives? An example of the latter is the jostling for power and positions in universities and professional bodies. The shadow between aspiration and practice is not unique to any profession or vocation. In many ways it represents mundane reality. The point is that modern professions are subject to an inner dynamic that occludes reaction on the ethical self. What we can learn from Gandhi is that in a very profound sense (to invert Ludwig Wittgenstein) deeds are words. ${ }^{170}$

It is imperative that those making legal decisions about the very nature of particular regimes become aware of the lived reality of the Global South and the dynamics that spur on international law and its institutions. The Report of the UN Secretary-General's Panel of Experts on Accountability in Sri Lanka's (March 2011) recommendation for the establishment of an "independent international

\footnotetext{
168 Ibid.

169 For a much more nuanced critical examiniation of Mohandas Karamchand Gandhi, see: Srinivas Burra, "Twail's Others: A Caste Critique of Twailers and their Field of Analysis" 33 (2016) Windsor YB Access Just 111.

170 Ibid at 1170 .
} 
mechanism" is a good illustration. ${ }^{171}$ Were the drafters of this recommendation ${ }^{172}$ aware of the serious problems with the role of the international criminal judiciary in amending the rules of evidence and procedure, or the serious concerns over witnesses and the rights of the accused within the current international ad hoc tribunals? ${ }^{173}$ Did they pay close attention to the manner in which witness testimony is elicited before the international criminal tribunals? Why did the UN Panel of Experts recommend the creation of an international mechanism when they should have known about the problems international criminal institutions are facing? Unpacking the rationale for these questions is another project. ${ }^{174}$

International lawyers and scholars have an ethical obligation to relay their claims to actual evidence from the ground (based on ethnographic research), rather than relying on antiquated notions about the nature of law and our global society. Such a reflection arrives full circle to the various interdisciplinary interventions that the Global South is a site for new learning about old problems. The various scholars participating in these discussions argue that contemporary actors, norms and processes are reconfiguring our understandings of the core-and-periphery. ${ }^{175}$ Thus to grasp the history of the present, both empirically and theoretically, we must study the Global South. ${ }^{176}$

\section{CONCLUSION}

International law and international institutions are intimately involved in the lives of the people of the Global South. Yet theories of global governance such as global constitutionalism and global administrative law are limited in their scope, and ignore the significant importance of the Global South within the global order. Throughout this paper, I tackled the means by which we can move these problems. As a means to build bridges between theories of global governance and the people of Global South, I articulated a modest proposal of engagement to link global governance with the Global South and incorporate its respective literature.

171 UN Secretary-General's Panel of Experts on Accountability in Sri Lanka, Report of the UN Secretary-General's Panel of Experts on Accountability in Sri Lanka, UNSGOR, 2011, SG/SM/13791 HR/5072; United Nations Secretary General's Panel's Report, Recommendation 1: Investigation (B): The Secretary General should immediately proceed to establish an independent international mechanism, whose mandate should include the following concurrent functions:

(i) Monitor and assess the extent to which the Government of Sri Lanka is carrying out an effective domestic accountability process, including genuine investigations of the alleged violations, and periodically advise the Secretary-General on its findings;

(ii) Conduct investigations independently into the alleged violations, having regard to genuine and effective domestic investigations; and

(iii)Collect and safeguard for appropriate future use information provided to it, which is relevant to accountability for the final stages of the war, including the information gathered by the Panel and other bodies in the United Nations system.

172 In the example of UN Sri Lanka Panel, the drafters of the report were: Marzuki Darusman (Former Attorney General of Indonesia and Politician), Yasmin Sooka (Former judge of the Witwatersrand High Court), and Steven R Ratner (University of Michigan Law School Professor).

173 Xavier, "Looking for 'Justice"”, supra note 61.

174 Ibid.

175 Comaroff \& Comaroff, supra note 32 at 117.

176 Ibid at 7, 117. 
In this paper, I relied on interdisciplinary insights to address current gaps in global governance theories (global constitutionalism and global administrative law). This article was organised around whether or not there is a need to learn from the Global South when theorising global governance, and if that need exists, how can we gain this knowledge?

At the outset, I explored the state of current global governance and suggested that it was predominantly Eurocentric. Then I posited that by attempting to answer both questions of should we learn from the Global South and how can we learn from the Global South, we can begin to transcend these limitations. In answering the first question of should we learn from the Global South, I relied on interdisciplinary scholarship and scholars working under the moniker of TWAIL to suggest that this question has already been answered.

In answering how we can learn from the Global South, I advanced two arguments. First, that international law and its institutions are mediated, moulded, and mitigated by multiple political and material forces. With that understanding, theories of global governance should take these factors into account by approaching international law and its institutions as a field of practice. Doing so invites a realisation that there is a need for further investigation of lived realities and the on-the-ground effects of global governance. This, in turn warrants the need for more robust ethnographic research, which can better chronicle the effects of global governance on the people of the Global South. Similarly, my second argument sought to locate the role of the international law scholar and international lawyer in contending with the lived realities of the Global South. I argued that as intellectuals, both international lawyers and international law scholars have a duty to transform and improve the material reality of the people of the Global South.

In the end, this paper has raised more questions than it has provided concrete answers. However, it is apparent that there is much work to be done to reorient how we theorise global governance. Increasingly robust ethnographies focusing on the various global governance institutions and their relationship to the Global South are urgently needed. Within the field of international criminal law, for example, there is a need to trace how local officials in countries like Sri Lanka handle the process of transitional justice. How judges and advocates before the local courts conceptualise and articulate transitional justice in both public and private law matters. By thinking about the local responses to transitional justice, a more fulsome international understanding can be developed.

What would global governance from the Global South entail? What does constitutionalism of the South look like? What are its possible features? Why is this a viable project? Should scholars and practitioners engage in this type of theorising?

These questions highlight the need for a theoretical foundation and an increasingly nuanced understanding of how international law and its institutions are functioning in the global order. By building bridges between theory and practice, between the Global South and global governance, we ensure that international law, international institutions and global governance can be inclusive of the people of the Global South. 